\title{
Community Engagement Practice through Service-Learning in Public Relations Class
}

\author{
Titi Nur Vidyarini* and Yustisia Ditya Sari \\ Communication Science Department, Faculty of Communication, Petra Christian University, \\ Siwalankerto 121-131, Surabaya, Indonesia
}

\begin{abstract}
This article explores the concept of corporate social responsibility in conjunction with the service-learning method. The focus of the exploration is a corporate social responsibility class which took place in Simokerto sub-village in Surabaya, Indonesia. The researcher used secondary analysis of the relevant documents from the Service-Learning program. The collaboration between the university's department of communication science, the World Vision Indonesia (WVI) Urban Surabaya that acted as the facilitator and provider of community and the students as the agents of service learning was enabled with an objective of the application of theories, an increased students' comprehension and benefits for the community itself. The findings of the research were highlighted in three aspects, first, the theories applied in the boundaries of the community's condition, having said that service-learning is a suitable method to cultivate the concept of CSR to Public Relations students. Second, the students experienced an increased comprehension from the active application of their knowledge and a changed in perception about others. Third, the active acceptance from the community and the role of the NGO enabled an uneventful service-learning program.
\end{abstract}

Keywords: Communication, public relations, service-learning, university.

\section{Introduction}

Corporate social responsibility has been announced through the years as something supposedly conducted by corporations. It began in the early 1950 s to 1960 s where principle of charity was countered by the principle of stewardship, in which corporations were acted as benefactor instead of steward [1]. In 1990s, Gro Bruntland devised the term sustainability, this term provide the anchor to guide the directions of corporations' social responsibility. Sustainability is "the principle of ensuring that our actions today do not limit the range of economic, social, and environmental options open to future generations" [2]. Corporate social responsibility "CSR is the voluntary actions that a corporation implements as it pursues its mission and fulfills its perceived obligations to stakeholders, including employees, communities, the environment, and society as a whole" [3]. Thus, CSR does not

\footnotetext{
${ }^{*}$ Corresponding author: vidya@petra.ac.id
} 
hinder the corporations' value for money, but adjusting them as not sacrificing the needs of future generation.

Indonesia enacted the promulgation of the Law no 40, 2007. It stated that all limited liability companies must performed their social and environment responsibility [4]. With this regulation, the companies can be charged by a lawsuit when their action were seen as destructing the environment. With the mandatory requirement of CSR, many companies have to return to what Elkington [2] said about the triple bottom line (people, planet, and profit). The focus of the corporation's is to reach the three important aspects, in which they should not undermine the necessary responsibility towards their stakeholders, including the shareholder.

The existence of public relations as a business unit or a practitioner has existed for many years. In relations to the conduct of corporate social responsibilitypublic relations is one of the departments which assigned to conduct the CSR of a company, in which the main role is to relate the company's policy with its stakeholder or publics. According to PR News, PR is a management function that focuses on public attitudes and effort to earn the publics' acceptance towards the company's policies [5]. Other experts defined public relations as a communication management [6], a science to analyze trends and consequence (1978 World Assembly of PR in Mexico City) [5], and also according to Harlow, Public relations is a distinctive management function which helps establish and maintain mutual lines of communication, understanding, acceptance and cooperation between an organization and its publics... serving as an early warning system to help anticipate trends; and uses research and ethical communication techniques as its principal tools [7].

Public relations plays a significant role in supporting business objective, explaining policies, increasing awareness, focus the publics' attention on issues, sustaining image and reputation, and other related to corporation's interest [8]. In Indonesia, public relations have been around since the 1950s, starting from the government effort to the corporations' awareness to reach the publics [9]. The growth of PR in Indonesia is significant, since there are multitudes of investment and the recent government's policy for the development of various infrastructures across the nation. Public relations educations are also growing rapidly to provide the needs of corporations for PR practitioners. From a survey conducted by Weber Shandwick PR agency to 100 public relations students participate in internships, $91 \%$ students stated that the material they learn in universities were applied during their public relations internships in various companies and PR agencies [10]. The public relations education thus can be considered as maintaining the same curriculum as required by the end users of the students after they are graduated. Universities performed as a basis of learning and practicing through indoor (classrooms) and outdoor laboratories (industries, societies).

Service-learning is essentially combining "service to the community with academic study...students study an academic course in a field that is connected with their service in the community" [11]. Service-learning serves as living laboratories for students to apply their knowledge into practice. In Indonesia, service-learning program is known as Kuliah Kerja Nyata-KKN in which the students participate in community service work outside their classes. Community service program is an independent program - detached from specific units of class - in which students from various majors are localized in remote areas to develop the area. Service-learning activities — on the other hand — which embedded in the students courses are now growing rapidly. Besides the compulsory KKN as performed by the public universities in Indonesia, many universities have enacted service-learning as a short-term community service program. The service-learning is tailored to each specific course.

In relations to public relations education, service-learning provides the pseudo-practice before the real practice of public relations. In particular with the corporate social 
responsibility scenario, there is a growing concern for cases of failed corporate social responsibility, such as Union Carbide factory in India, Nike's association with sweatshops, and other cases of accidents occurred in various major corporations in the world [3]. Before entering the real world of corporations, service-learning can be one solution to understand the needs of community and relate it to the interest of the public.

This article discussed the growing importance of preparing public relations students to face communities as their future publics through activating corporate social responsibility course. The case study is Corporate Social Responsibility course in Petra Christian University in Surabaya, Indonesia. The course is conducted one semester for each academic year, involving only public relations students, specializing in corporate public relations.

\section{Literature on communication and service-learning}

In the higher education system, various methods have been used as means of learning. Public relations education combined both theories and practices in the curriculum, in order to familiarize the students with the framework of public relations activities. The needs for a strategic public relations management was the result of an increasing competitiveness of business world and the results of a successful PR program for the organization [12]. The need for corporate communicator encompass the ability to recognize and diagnose the communication-related problems and emerge with the strategies and tactics to overcome those problems [13].

The issues of corporate social responsibility have become one of the lessons being taught in universities. The roles of communication in the implementation of CSR program was highlighted in several research related to community activism [14], the use of social media Twitter [15], customer response on banking companies [16], and CSR reporting from the less economically powerful stakeholder [17]. The communication aspects of CSR were being scrutinized as a form of accountability from the stakeholders' perspective. Thus it is crucial for public relations students to learn CSR as a responsible and accountable program. More than that, one of the communication challenge is communicating with the opinion leaders [18]. Service-learning is one of the method of achieving the practice aspect of public relations activity in higher education.

Jacoby [19] articulated service-learning as a mode of learning that "encouraged colleges and universities of all types to reexamine and bolster their missions to prepare students to become civically engaged citizens." Service-learning has three principles as stated by Deeley [11] which are "enhanced sense of citizenry...the accelerated intellectual development...and personal development". In essence the goal for service-learning is to enhance the students' scientist and activist side. However, certain students' resistance toward the method of learning might emerge during the journey and can be expected. As Jones, Gilbride-Brown and Gasiorski [20] implied three kinds of students resistance profile that surface during the process, they are known as, first, the "The Good Volunteer", these students are the good helper and pretty happy on the site; second profile, "The Politely Frustrated" are students who don't want to disrupt the activity for their good grades; third, "The Active Resister", these students tend to be problematic in the service site and openly confronted the education process in the classroom. In order to smoothly manage the learning process, Swaminathan [21] encouraged educators to listen to the student voices and embed student's experience in the curriculum of service-learning. 


\section{The setting of the observation and fieldwork}

In this study, three areas of public relations based class with service-learning method were explored, i) the theory application in the community, ii) the implication of service learning for students' understanding, iii) the participation of community and NGO. The three areas were researched in accordance with the concept of Public Relations program planning, in that sense the communication side of public relations and the curriculum of servicelearning.

The course was designed to enable the students to create a two-way communication, identify PR publics, prevent communication crisis, and increasing the students' skill for researching, communicating, reporting, editing, and applying PR functions through corporate social responsibility [22]. The setting of the course was thesub-district Simokerto in North Surabaya. This sub district was a part of World Vision Organization Urban Surabaya's area of development (ADP). As one of the poor area in Surabaya, the sub district was populated with underprivileged families. The NGO was focusing on the welfare of the children. The area has become the ADP for $2 \mathrm{yr}$ from its $15 \mathrm{yr}$ program. The NGO cooperates with universities, corporations and the local government.

\section{Theory application in the community}

According to Coombs and Holladay [3], PR practitioner can perform Corporate Social Responsibility with a communication approach. The approach comprises of scanning and monitoring, formative research, creating CSR initiative, communicating CSR, and evaluating.

\subsection{Scanning the community}

In this course the students were not involved with the community from day one of the semester. The students were taking classes about the basics of CSR and public relations, the strategic CSR, understanding the communities and conducting social mapping. They were grouped into four groups, based on the number of sub-villages under the sub district. The representative from the NGO explained the situation of ADP and the students presenting initial ideas about the programs they were planning. The students then went into the community to meet with the representative of each sub-village accompanied by the representatives of WVI. During the meeting, they surveyed the area to know the real situation of the community.

\subsection{Planning the program}

The students returned to the class and planning the program based on the preliminary observations and interviews with the representative of the area. In relations to the core program from WVI and the university's core as educational institution, the students were focused on environmental themes such as sanitation. The initial mini research showed that the main problems of the community were poverty, children hygiene, and reading habit. The students highlighted the needs for elementary school students in the area. The target of the program was the children of the community and not the parents. Based on the reports of previous CSR course program and from the NGO, communicating with the parents were proven to be difficult with hindrance from language boundaries, characteristic of the people and it would deviate from the core objective of both institutions. In the planning process, 
the students consulted the lecturers, the NGO and also their own group's SWOT (Strength, Weakness, Opportunity and Threat). Because of the zero budget from the university, the students provided the materials on their own expenses.

\subsection{Implementing the program}

There were four programs in four different sub-villages.

\subsubsection{Sudah Bersihkah Aku? (Am I Already Clean?)}

The program covered four meetings with different themes. The group taught 26 children about how to maintain a healthy body, in which they taught and practiced how to keep a healthy hands and feet, teeth, and overall body. They also use coloring activity to emphasised their messages.

\subsubsection{Kesehatan Dimulai dari Diriku (Health Started From Me)}

Through this program, the group introduced the concept and practice of healthy body and environment. They use puppet show, planting medicinal plants, stor- telling and talent show to teach 23 children about health.

\subsubsection{Membaca itu Menyenangkan (Reading is Fun)}

This group perceived the need to increase reading habit of the community. With 25 children as participant, the group did storytelling, role playing, and public speaking/reading.

\subsubsection{Bersih Diriku Nyaman Hidupku (The Clean Me, Comfortable Life for Me)}

The group taught 21 to 25 students each week about self-cleanliness. They use activities such role playing, creating handicraft and reviewing the material with the children.

\subsection{Evaluating the program}

The evaluation conducted through several simple methods such as interviewing the parents about the habit change, reviewing the material with the children, and discussion with the representative of WVI. Overall finding, the students were well accepted in the area, the children experiencing a change in habit, and the increased knowledge of the participant about the subjects being taught and practiced.

\section{The impact for students' understanding}

After the service-learning the students were obliged to write a reflection paper. From the reflection papers obtained, it was found that the students have diverse opinions. For instance, student $\mathrm{S}$ reflected about the different economic condition faced by the children in the community. She also stated that the underprivileged circumstances did not hinder the children to thrive. One point she highlighted was about independence. Student A contemplated the relations with the community. He could describe the overall program and 
his roles in the program. This student felt that the experience had increased his perceptiveness towards other people and wisdom in his utterance towards smaller children. Overall, most of the students felt they were able to know and act to appreciate others; create a warm community; mingle with people of different characteristic and social classes and to encourage children from lower economic status to have the drive to study.

\section{Community participation and the role of NGO}

The community that served as the location for the students' CSR was an Area Development Program of the World Vision Indonesia. At the initial meeting, the students were accompanied by the representatives of the NGO to approach the key person of each subvillage. The key persons were called kader (Indonesian), they received training on healthcare, hygiene, children issues and become the middle person between the NGO and the overall community. During the meeting, the representative of each sub-village listens to the students' ideas and also provides feedbacks on issues important to them. After the initial meeting, the students then observe the neighborhood and conducting their SWOT analysis. The NGO provided one representative for each sub-village to attend the program. The kader were also present during the event. Mostly, they were watching the children's behavior without disturbing the overall event. The representative of the NGO brought snacks for the children.

The community welcomed the students through the provision of suitable place and allowing their children to come to the events. The children were aged between 8 yr to $10 \mathrm{yr}$. They came to the events after school and before they performed their Quran lessons or mengaji (Indonesian). The students reports revealed that the children were excited and receiving the information in a positive light. They were proven to be diligent and accepting the students. The lessons given were taught in various forms of communication, such as doll stage, creating handicraft from used items, plays, learning how to plant, reading and public speaking and also watching videos. The modes of learning were chosen as not to bore the children and to attract them to come every week. At the end of the program, the students and the children were reported as inseparable.

\section{Conclusion}

First, while the CSR course did not involve a real business corporation, the key points of the lesson was to map the community, identify the public and create messages for the public. There were no empirical researches regarding the social mapping process from the students. Nevertheless the students conducted simple interview and focus group to probe the community's problem. Second, in planning the CSR program the students searching advices from several sources, the NGO, the lecturer, an expert in the field and resort to their own findings at the initial meeting. Third, during the implementation of the program, the students were 'forced' to cooperate with the members of the group for one purpose of achieving the goal of the program. The programs executed were planned in accordance with the students' abilities, financial situation and the community condition. Nevertheless, the program tailored for the children were suitable because they received positive feedbacks in the forms of repetition of information from the children being asked about the lessons, the numbers of children coming every week and the students experienced an increase in selfesteem and communication skill. The students in this step faced the challenge of actually communicating with the parents of the children. The NGO acted as the go-in-between and helped them to open the communication channel with the community. The relations 
between corporations (and PR as the representative) and NGO was gained through their own interaction with NGO. Fourth, in the program's evaluation process, the students used several means to evaluate: simple quiz at the end of every week meeting, the kids were told to repeat the information they received from previous event; sharing session with the children parents to know the change of behavior; questionnaire for the parents which asked the children's comprehension about the lesson on reading habit.

In the process of evaluation, the students also learn about themselves and their relations with others. The community they served had become the learning community for both parties. The focus of the course was to enhance the students' competence to applied communication aspect through CSR program. The students were met with communication challenge within their own group, with the NGO and most of all with the community. The cooperation between the university and the NGO was needed to establish a common ground of humanitarian objectives for both. The CSR course needs to reformat several things. First, the students have to delve in the community sooner. At the same time, they can take the role of CSR's practitioner earlier. Second, the students should be given deeper insights on how an NGO works and what kinds of relationship NGOs have with corporations and the government. Third, activating a community relations simulation, the students profiled their community, design the communication plan to approach opinion leaders, communicate and applying the program before the actual implementation.

\section{References}

1. I. Solihin, S.D. Citra. Corporate social responsibility from charity to sustainability. Jakarta: Salemba Empat, (2009). p. 22. [in Bahasa Indonesia]. http://opac.lib.ugm.ac.id/index.php?mod=book_detail\&sub=BookDetail\&act=vie w\&typ $=$ htmlext\&buku id $=699142$ \&obyek $\mathrm{id}=1$

2. J. Elkington. Cannibals with forks: The triple bottom line of 21 st century business. New Jersey: John Wiley and Son (1999). https://www.amazon.com/CannibalsForks-Triple-Century-Business/dp/1841120847

3. T.W. Coombs, S.J. Holladay. Managing Corporate Social Responsibility: A Communication Approach, New Jersey: Wiley-Blackwell, (2012), p. 7-8, 13-15, 63, 121. https://www.wiley.com/enus/Managing+Corporate + Social + Responsibility $\% 3 \mathrm{~A}+\mathrm{A}+$ Communication + Approa ch-p-9781444336450

4. President of Indonesia. Undang-undang Republik Indonesia nomor 40 tahun 2007 tentang perseroan terbatas. [Law of the Republic of Indonesia number 40 of 2007 concerning limited liability companies] [Online] from http://eodb.ekon.go.id/download/peraturan/undangundang/UU_40_2007.PDF (2007). [Accessed on 21 June 2017]. [in Bahasa Indonesia].

5. D.L. Wilcox, G.T. Cameron, B.H. Reber. Public relations strategies and tactics. Boston: Pearson (2015). p. 34. https://www.amazon.com/Public-RelationsStrategies-Tactics-11th/dp/0205960642

6. J.E. Grunig,, T. Hunt. Managing Public Relations, New York: Holt, Rinehart and Winston, inc. (1984). https://www.amazon.com/Managing-Public-RelationsJames-Grunig/dp/0030583373

7. R. Tench, L.Yeomans. Exploring public relation. London: Pearson Education Limited (2006). https://www.amazon.com/Exploring-Public-Relations-RalphTench/dp/0273715941 
8. N. Stone, The management and practice of public relations. London: Macmillan Business, (1995). p. 25-26. https://www.macmillanihe.com/page/detail/themanagement-and-practice-of-public-relations-normanstone $/$ sfl=barcode\&st $1=9780333609767$

9. Hananto, H. Sejarah dan perkembangan public relation. [Online] from https://hisyamhananto.wordpress.com/2010/03/07/sejarah-dan-perkembanganpublic-relations/ (2010) [Accessed on 15 September 2017].

10. B. Chailani. Public relations education in Indonesia:

Moving forward with promise, http://webershandwick.co.id/en/public-relationseducation-in-indonesia-moving-forward-with-promise/, (2015). [Accessed on 26 June 2017].

11. S.J. Deeley,. Critical perspective on service-learning in higher education. London: Palgrave-McMillan (2015). p. 19, 34.

https://www.palgrave.com/br/book/9781137383242

12. E.W. Austin, B.E. Pinkleton. Strategic public relations management (2nd). New Jersey: Lawrence Erlbaum Associates (2011). p. 1. https://trove.nla.gov.au/work/20392275

13. .J. Cornellisen. Corporate communication: Theory and practice. London: Sage, (2004). p. 19. https://www.amazon.com/Corporate-Communications-ProfessorJoep-Cornelissen/dp/0761944354

14. K. Demetrious. Social Responsibility Journal, 4,1/2:104-119,(2008). https://www.emeraldinsight.com/doi/abs/10.1108/17471110810856875

15. M. Etter. Journal of Communication Management, 18,4:322-342(2014). https://www.emeraldinsight.com/doi/abs/10.1108/JCOM-01-2013$0007 ? \mathrm{mbSc}=1 \&$ mobileUi $=0 \&$ full $\mathrm{Sc}=1 \&$ full $\mathrm{Sc}=1 \&$ journalCode $=$ jcom

16. A. Pérez, I.R. del Bosque. Journal of Product \& Brand Management, 24,5:481493(2015). https://www.emeraldinsight.com/doi/abs/10.1108/JPBM-12-2014-0759

17. Md.M. Hossain, M. Alam. International Journal of Accounting \& Information Management, 24,4:415-442(2016).

https://www.emeraldinsight.com/doi/abs/10.1108/IJAIM-05-20160064? full $\mathrm{Sc}=1$ \&journalCode $=$ ijaim

18. J. Dawkins. Journal of Communication Management, 9,2:108-119(2005). https://www.emeraldinsight.com/doi/abs/10.1108/13632540510621362

19. B. Jacoby, Associates. Building partnerships for service-learning. San Fransisco: Josey Bass (2003). https://www.amazon.com/Building-Partnerships-ServiceLearning-Associates/dp/0787958905

20. S. Jones, J. Gilbride-Brown, A. Gasiorski, "Underside" of service-learning: student resistance and possibilities. In: Service-learning in higher education: Critical issues and direction, D.W. Butin (ed.). New York: Palgrave Mcmillan, (2005) https://link.springer.com/chapter/10.1057/9781403981042_1

21. R. Swaminathan, "Whose school is it anyway?" Student voices in an urban classroom. In: Service-learning in higher education: Critical issues and direction, D.W. Butin (ed.). New York: Palgrave Mcmillan (2005).

https://link.springer.com/chapter/10.1057/9781403981042_2\#citeas

22. Communication Science Department (CSD). SAP Tanggung Jawab Sosial Perusahaan. [SAP Corporate Social Responsibility]. Surabaya: CSD (2013). [in Bahasa Indonesia]. 